\title{
PENGARUH PEMBERIAN ASAM HUMAT DAN K TERHADAP PERTUMBUHAN DAN PRODUKSI TANAMAN TOMAT (Lycopersicum esculentum Mill)
}

\author{
Hendi Victolika, Sarno \& Yohannes Cahya Ginting \\ Jurusan Agroteknologi, Fakultas Pertanian Universitas Lampung \\ Jl. Prof. Soemantri Brodjonegoro, No. 1, Bandar Lampung 35145 \\ E-mail: hendivictolika@yahoo.co.id
}

\begin{abstract}
ABSTRAK
Tanaman tomat merupakan tanaman hortikultura yang akan tumbuh dan berproduksi baik pada tanah dengan kandungan bahan organik yang tinggi. Asam humat merupakan hasil ekstraksi bahan organik yang dapat dijadikan sebagai subtitusi pupuk kandang atau kompos. Salah satu bahan yang dapat diekstrak untuk menghasilkan asam humat adalah batubara muda. Dalam peningkatan produksi, maka tidak terlepas dari pemupukan. unsur K salah satu unsur hara essensial yang berperan dalam proses pembentukan dan translokasi fotosintat.Penelitian ini bertujuan untuk mengetahui pengaruh asam humat, pupuk K, serta interaksi dari asam humat dan pupuk $\mathrm{K}$ terhadap pertumbuhan dan produksi tanaman tomat Lycopersicum esculentum Mill. Penelitian ini dilakukan di rumah kaca Fakultas Pertanian Universitas Lampung dengan metode RAL Faktorial $2 \times 5$. Faktor pertama yaitu pupuk $\mathrm{K}$ yang berasal dari $\mathrm{KCl}\left(\mathrm{k} 0=\operatorname{tanpa~} \mathrm{KCl}, \mathrm{k} 1=\right.$ dengan $\mathrm{KCl} 6 \mathrm{~g}$ polybag $\left.{ }^{-1}\right)$. Faktor kedua yaitu konsentrasi asam humat $\left(0,50,100,150,200 \mathrm{mg} \mathrm{L}^{-1}\right.$. Tanah untuk media tanam adalah jenis Ultisol yang diambil dari Politeknik Negeri Lampung di Jl. Soekarno Hatta No 10 Rajabasa Bandar Lampung. Setiap polybag berisi $10 \mathrm{~kg}$ tanah. Homogenitas ragam data pengamatan diuji dengan Uji Bartlett. Data yang sudah homogen dianalisis Uji-F. Analisis lanjut menggunakan uji perbandingan dan polinomial ortogonal. Hasil penelitian menunjukkan bahwa pada perlakuan tanpa $\mathrm{K}$, asam humat dapat meningkatkan jumlah daun, indeks kehijauan daun, dan bobot buah per tanaman, tetapi bila diberi pupuk K hubungannya tidak nyata dan menurun secara linier pada indeks kehijauan daun dan jumlah daun.
\end{abstract}

Kata Kunci : Asam humat, K, tomat (Lycopersicum esculentum Mill).

\section{PENDAHULUAN}

Tanaman tomat (Lycopersicum esculentum) merupakan jenis tanaman hortikultura yang dibutuhan masyarakat baik dalam bidang konsumsi maupun bahan baku industri. Untuk memenuhi kebutuhan tersebut maka upaya yang dilakukan adalah peningkatan produksi tanaman tomat. Tanaman tomat umumnya membutuhkan bahan organik yang tinggi untuk mencapai produksi yang optimal (Pitojo, 2005). Hal tersebut telah dibuktikan bahwa pemberian pupuk kandang dengan dosis 10 ton ha $^{-1}$ mampu memberikan hasil positif terhadap peningkatan produksi tanaman tomat (Mulyati dkk., 2007). Akan tetapi, jumlah dosis yang diberikan tersebut dinilai kurang efisien dan ekonomis oleh pihak tertentu, karena membutuhkan banyaknya biaya dan tenaga kerja.

Asam humat merupakan senyawa organik yang telah mengalami proses humifikasi dan larut dalam alkali. Asam humat dapat berpengaruh secara langsung dan tidak langsung. Secara tidak langsung yaitu memperbaiki status kesuburan tanah baik dalam sifat fisik, kimia, maupun biologi tanah (Tan, 1992). Dengan meningkatnya status kesuburan tanah, maka serapan hara tanaman akan meningkat, sehingga pertumbuhan dan produksi tanaman akan semakin optimal. Pengaruh asam humat secara langsung yaitu mampu memperbaiki proses metabolisme didalam tanaman, seperti meningkatkan proses laju fotosintesis tanaman (Heil, 2005), karena meningkatnya kandungan klorofil pada daun (Ferrara dan Brunetti, 2010).

Beberapa peneliti menunjukkan bahwa pemberian asam humat melalui daun mampu meningkatkan pertumbuhan, serapan hara, serta produksi pada berbagai tanaman, antara lain bayam (Sarno dan Eliza, 2012), kacang faba (El-Ghamry dkk., 2009), dan tembakau (Mylonas dan McCants, 1980). El-Ghamry dkk.(2009) melaporkan bahwa pemberian asam humat melalui daun dapat meningkatkan tinggi tanaman, jumlah cabang dan daun per tanaman, jumlah polong per tanaman, serta berat 100 biji kacang faba. Sarno dan Eliza (2012) mendapatkan bahwa pemberian asam humat dapat meningkatkan tinggi tanaman, jumlah daun, bobot kering tajuk, bobot kering akar, dan serapan $\mathrm{N}$ 
pada tanaman bayam dengan konsentrasi $128-165 \mathrm{mg}$ $\mathrm{L}^{-1}$.

Dalam peningkatan produksi, maka tidak terlepas dari pemupukan. unsur K salah satu unsur hara essensial yang berperan sebagai penyusun komponen tanaman seperti protoplasma, lemak, dan selulosa, tetapi berperan utama dalam pengaturan mekanisme fotosintesis, translokasi karbohidrat, sintesa protein (Hanafiah, 2005). Syakir (2012) menjelaskan bahwa pemberian pupuk K mampu meningkatkan jumlah tanaman nilam, dan mampu meningkatkan bobot buah per tanaman pada tanaman tomat (Nugroho, 2012).

Penelitian mengenai pemberian asam humat melalui penyemprotan daun dengan pemberian pupuk $\mathrm{K}$ masih belum banyak dilakukan di Indonesia. Oleh karena itu pemberian asam humat melalui daun dengan pupuk $\mathrm{K}$ diharapkan dapat meningkatkan produksi tanaman, khususnya untuk budidaya tanaman hortikultura.Berdasarkan uraian tersebut maka perlu dilakukan penelitian yang bertujuan untuk mengetahui pengaruh interaksi dari asam humat dan pupuk $\mathrm{K}$ terhadap pertumbuhan dan produksi tanaman tomat.

\section{BAHAN DAN METODE}

Penelitian ini dilakukan di Rumah Kaca dan Laboratorium Ilmu Tanah Fakultas Pertanian Universitas Lampung dari April hingga Agustus 2013. Contoh tanah yang digunakan berasal dari Kebun Percobaan Politeknik Negeri Lampung. Alat-alat yang digunakan adalah timbangan, cangkul, ayakan, polybag, dan alat-alat laboratorium untuk analisis, sedangkan bahan-bahan yang digunakan adalah batubara muda, $t$ anah media tanam adalah jenis Ultisol yang berasal dari Kebun Percobaan Politeknik Negeri Lampung (untuk media tanam), benih tomat varietas Karina, pupuk N (Urea), P (SP-36), K (KCl), dan bahan-bahan kimia untuk mengekstrak asam humat.

Penelitian ini disusun secara faktorial $2 \times 5$ dalam Rancangan Acak Lengkap (RAL) dengan tiga kali ulangan. Faktor pertama adalahpupuk $\mathrm{K}$ yang berasal dari $\mathrm{KCl}$ yaitu $\mathrm{K} 0=$ tanpa $\mathrm{KCl}$ dan $\mathrm{K} 1=$ pemberian dosis $\mathrm{KCl} 6 \mathrm{~g}_{\text {polybag }}{ }^{-1}$. Faktor ke dua adalah pemberian asam humat yaitu $\mathrm{H} 0=0 \mathrm{mg} \mathrm{L}^{-1}, \mathrm{H} 1=50 \mathrm{mg} \mathrm{L}^{-1}, \mathrm{H} 2=$ $100 \mathrm{mg} \mathrm{L}^{-1}, \mathrm{H} 3=150 \mathrm{mg} \mathrm{L}^{-1}$ dan $\mathrm{H} 4=200 \mathrm{mg} \mathrm{L}^{-1}$. Untuk menguji homogenitas ragam digunakan $\mathrm{Uji}$ Bartlett. Data yang sudah homogen dianalisis dengan uji-F. Pemisahan nilai tengah dilakukan dengan uji perbandingan dan olinomial ortogonal pda taraf nyata 1 dan $5 \%$.

Proses ekstraksi asam adalah menimbang $100 \mathrm{~g}$ batubara yang telah dipersiapkan lalu dimasukkan ke dalam erlenmeyer 2 L sebanyak 6 buah. Lalu menambahkan $1000 \mathrm{ml}$ larutan $0,1 \mathrm{~N} \mathrm{NaOH}$ dan dimasukkan ke dalam batang pengaduk (strirer) lalu diletakkan pada hotplate yang dipanaskan pada suhu 80 ${ }^{\circ} \mathrm{C}$ selama 2 jam. Lalu menambahkan $\mathrm{HCl} 6 \mathrm{~N}$ hingga pH menjadi 1-2, lalu dibiarkan selama 24 jam agar berkoagulasi. Kemudian larutan tersebut dipindahkan kedalam sentrifus lalu di sentrifus pada putaran 6000rpm selama 30 menit. Kemudian memisahkan endapan (asam humat) dengan larutan beningnya (asam fulvat) ke dalam labu erlenmeyer $500 \mathrm{ml}$. Kemudian asam humat tersebut dicuci dengan menambahkan aquades sebanyak $200 \mathrm{ml}$ lalu dikocok selama 5 menit sebanyak 5 kali. Selanjutnya asam humat dikeringoven pada suhu $60{ }^{\circ} \mathrm{C}$ dan disimpan ke dalam desikator. Lalu mengukur kadar air asam humat dengan cara menimbang $0,1 \mathrm{~g}$ ke dalam alumunium foil, lalu dipanaskan pada oven bersuhu $105^{\circ} \mathrm{C}$ selama 24 jam, kemudian dimasukkan kedalam desikator, kemudian menimbang 50, 100, 150, $200 \mathrm{mg}$ asam humat tersebut, lalu dimasukkan ke dalam erlenmeyer $2 \mathrm{~L}$, dan menambahkan $250 \mathrm{ml} \mathrm{NaOH}$. Kemudian setelah ditimbang lalu diletakkan diatas hotplate lalu diaduk dengan stirer dengan suhu $70^{\circ} \mathrm{C}$ hingga larut sempurna. lalu dipindahkan kedalam gelas beacker $2 \mathrm{~L}$ lalu diukur $\mathrm{pH}$ nya, kemudian $\mathrm{pH}$ nya dinetralkan dengan $\mathrm{H}_{2} \mathrm{SO}_{4}$. Kemudian larutan tersebut dibuat sesuai yang dibutuhkan.

Polybag berisi $10 \mathrm{~kg}$ tanah diberi Kyang sumbernya dari $\mathrm{KCl}$ sesuai dengan perlakuan yaitu $6 \mathrm{~g}$ $\mathrm{KCl} /$ polybag dan ditanami benih tomat. Pupuk dasar $\mathrm{N}$ dan P diberikan sebagai SP 36 sebanyak 9 g polybag $^{-1}$ dan Urea sebanyak $8 \mathrm{~g}$ polybag ${ }^{-1}$. Tiap polybag ditanami 1 bibit tomat. Penyiraman dilakukan setiap hari pada pagi dan sore hari, dan penyiangan dilakukan jika ada gulma yang tumbuh pada sekitar tanaman Aplikasi asam humat dilakukan dengan penyemprotan melalui daun. Penyemprotan dilakukan setelah tanaman berumur 20, 40, dan 60 HST. Pemanenan dilakukan pada 80 HST. Variabel yang diamati adalah tinggi tanaman, jumlah daun, indeks kehijauan daun, jumlah buah per tanaman, bobot buah per tanaman, dan bobot individu tomat.

\section{HASIL DAN PEMBAHASAN}

Tabel 1 menunjukkan bahwa jumlah daun, indeks kehijauan daun, bobot buah per tanaman, dan bobot individu tomat dipengaruhi oleh interaksi asam humat dan $\mathrm{K}$, sedangkan pemberian $\mathrm{K}$ yang diikuti pemberian asam humat tidak berpengaruh terhadap tinggi tanaman dan jumlah buah per tanaman. Bila dibandingan antara tanpa dan diberi $\mathrm{K}$, maka tampak bahwa pada tanpa dan pemberian asam humat $50 \mathrm{mg}$ 
Tabel 1. Pengaruh asam humat dan pupuk K terhadap pertumbuhan dan produksi tanaman tomat.

\begin{tabular}{|c|c|c|c|c|c|c|}
\hline \multirow{2}{*}{ Perbandingan } & TT & $\mathrm{JD}$ & IKD & JBP & $\mathrm{BBP}$ & BIT \\
\hline & \multicolumn{6}{|c|}{ (F-Hit dan ang ka dalam kurung merupakan selisih (\%)) } \\
\hline \multicolumn{7}{|l|}{ Pupuk K } \\
\hline $\mathrm{P} 1: \mathrm{K} 0$ vs $\mathrm{K} 1$ & $\begin{array}{c}10,23 * * \\
(24,77)\end{array}$ & $\begin{array}{c}47,53 * * \\
(21,91)\end{array}$ & $\begin{array}{c}77,28 * * \\
(5,29)\end{array}$ & $\begin{array}{l}18,29 * * \\
(24,24)\end{array}$ & $\begin{array}{c}77,68 * * \\
(50,65)\end{array}$ & $\begin{array}{c}110,32 * * \\
(22,55)\end{array}$ \\
\hline \multicolumn{7}{|l|}{ Asam humat } \\
\hline $\begin{array}{l}\text { P2: H-linier } \\
\text { P3: H- kuadratik }\end{array}$ & $\begin{array}{l}0,03 \mathrm{tn} \\
3,03 \mathrm{tn}\end{array}$ & $\begin{array}{c}3,06 \text { tn } \\
14,46 * *\end{array}$ & $\begin{array}{c}0,00 \text { tn } \\
73,16 * *\end{array}$ & $\begin{array}{c}0,14 \mathrm{tn} \\
12,35 * *\end{array}$ & $\begin{array}{l}11,95 * * \\
27,75^{* *}\end{array}$ & $\begin{array}{l}80,16 * * \\
17,46 * *\end{array}$ \\
\hline \multicolumn{7}{|l|}{ Interaksi $\mathrm{KxH}$} \\
\hline $\begin{array}{l}\text { P4: P1 x P2 } \\
\text { P4: P1 x P3 }\end{array}$ & $\begin{array}{l}1,17 \mathrm{tn} \\
2,15 \mathrm{tn}\end{array}$ & $\begin{array}{c}25,00 * * \\
0,42 \text { tn }\end{array}$ & $\begin{array}{l}79,19 * * \\
29,77 * *\end{array}$ & $\begin{array}{l}0,57 \mathrm{tn} \\
0,00 \mathrm{tn}\end{array}$ & $\begin{array}{c}4,72 * \\
0,11 \text { tn }\end{array}$ & $\begin{array}{c}23,48 * * \\
0,94 \mathrm{tn}\end{array}$ \\
\hline \multicolumn{7}{|c|}{ Tanggapan Tanaman terhadap $\mathrm{H}$ pada } \\
\hline $\begin{array}{l}\text { K0 : H-linier } \\
\text { K1 : H-linier } \\
\text { K0 : H-kuadratik } \\
\text { K1 : H-kuadratik }\end{array}$ & $\begin{array}{l}- \\
- \\
- \\
-\end{array}$ & $\begin{array}{c}5,28 * * \\
22,78 * * \\
- \\
-\end{array}$ & $\begin{array}{c}39,60 * * \\
39,60 * * \\
98,14 * * \\
4,80 *\end{array}$ & $\begin{array}{l}- \\
- \\
- \\
-\end{array}$ & $\begin{array}{c}15,84 * * \\
0,83 \text { tn } \\
- \\
-\end{array}$ & $\begin{array}{c}95,19 * * \\
8,44 * * \\
- \\
-\end{array}$ \\
\hline \multicolumn{7}{|c|}{ Tanggapan Tanaman terhadap K pada } \\
\hline H0 : K0 vs K1 & - & $\begin{array}{c}30,63 * * \\
(30,30) \\
50,63 * *\end{array}$ & $\begin{array}{c}169,94 * * \\
(19,52) \\
16,00 * *\end{array}$ & - & $\begin{array}{l}23,02 * * \\
(107,80) \\
39,46 * *\end{array}$ & $\begin{array}{c}84,44 * * \\
(63,63) \\
15,76 * *\end{array}$ \\
\hline H1 : K0 vs K1 & - & $\begin{array}{c}(47,36) \\
1,41 \text { tn }\end{array}$ & $\begin{array}{l}(5,19) \\
2,30 \mathrm{tn}\end{array}$ & - & $\begin{array}{l}(81,41) \\
2,18 \mathrm{tn}\end{array}$ & $\begin{array}{c}(18,84) \\
22,28 * *\end{array}$ \\
\hline $\mathrm{H} 2: \mathrm{K} 0$ vs $\mathrm{K} 1$ & - & $(7,89)$ & $(1,98)$ & - & $(14,782)$ & $(22,63)$ \\
\hline $\begin{array}{l}\text { H3: K0 vs K1 } \\
\text { H4: K0 vs K1 }\end{array}$ & - & $\begin{array}{c}0,63 \mathrm{tn} \\
(8,33) \\
0,63 \mathrm{tn} \\
(8,57)\end{array}$ & $\begin{array}{l}0,08 \text { tn } \\
(0,35) \\
0,69 \text { tn } \\
(1,12)\end{array}$ & - & $\begin{array}{c}28,06 * * \\
(66,34) \\
3,44 \mathrm{tn} \\
(21,16)\end{array}$ & $\begin{array}{c}17,54 * * \\
(17,63) \\
2,01 \mathrm{tn} \\
(5,91)\end{array}$ \\
\hline
\end{tabular}

Keterangan : $*$ nyata pada taraf $5 \% ; * *=$ Sangat nyata pada taraf $5 \% ;$ tn $=$ tidak nyata pada taraf $5 \%$; $\mathrm{K} 0=$ Tanpa $\mathrm{KCl} ; \mathrm{K} 1=$ dengan pupuk $\mathrm{KCl} 6 \mathrm{~g} \mathrm{polybag}^{-1} ; \mathrm{H} 0=$ Tanpa asam humat; $\mathrm{H} 1$ = dengan asam humat $50 \mathrm{mg} \mathrm{L}^{-1} ; \mathrm{H} 2=$ dengan asam humat $100 \mathrm{mg} \mathrm{L}^{-1} ; \mathrm{H} 3=$ dengan asam humat $150 \mathrm{mg}$ $\mathrm{L}^{-1} ; \mathrm{H} 4=$ dengan asam humat $200 \mathrm{mg} \mathrm{L}^{-1}$. TT = tinggi tanaman, $\mathrm{JD}=$ jumlah daun, $\mathrm{IKD}=$ indeks kehijauan daun, JBP $=$ jumlah buah per tanaman, $\mathrm{BBP}=$ bobot buah per tanaman, $\mathrm{BIT}=$ bobot individu tomat.

$\mathrm{L}^{-1}$, jumlah daun dan indeks kehijauan daun yang diberi $\mathrm{K}$ sangat nyata lebih tinggi daripada tanpa diberi $\mathrm{K}$, namun apabila konsentrasi asam humat ditingkatkan, maka tidak menunjukkan perbedaan yang nyata. Pada bobot buah per tanaman yang diberi pupuk $\mathrm{K}$ dengan asam humat 0,50 , dan $150 \mathrm{mgL}^{-1}$ sangat nyata lebih tinggi dari pada tanpa diberi $\mathrm{K}$, dan pada bobot individu tomat yang diberi pupuk $\mathrm{K}$ dengan diikuti asam humat 0,50 , 100 dan150 $\mathrm{mgL}^{-1}$ sangat nyata lebih tinggi dari pada tanpa diberi K. Hal itu menunjukkan bahwa K dapat meningkatkan pertumbuhan dan produksi tanaman.Syakir (2012) menjelaskan bahwa pemberian pupuk K dapat meningkatkan jumlah tanaman nilam, dan Nugroho (2012)juga mengatakan bahwa K dapat meningkatkan bobot buah per tanaman pada tanaman tomat.

Gambar 1 menunjukkan bahwa pada tanpa K, pemberian asam humat dapat meningkatkan jumlah daun, bobot buah per tanaman, dan bobot indvidu tomat secara linier, untuk indeks kehijauan daun hubungannya meningkat secara kuadratik. Akan tetapi pada bobot buah per tanaman yang diberi pupuk K, maka hubungannya tidak nyata, sedangkan pada jumlah daun dan indeks kehijauan daun hubungannya menurun secara 

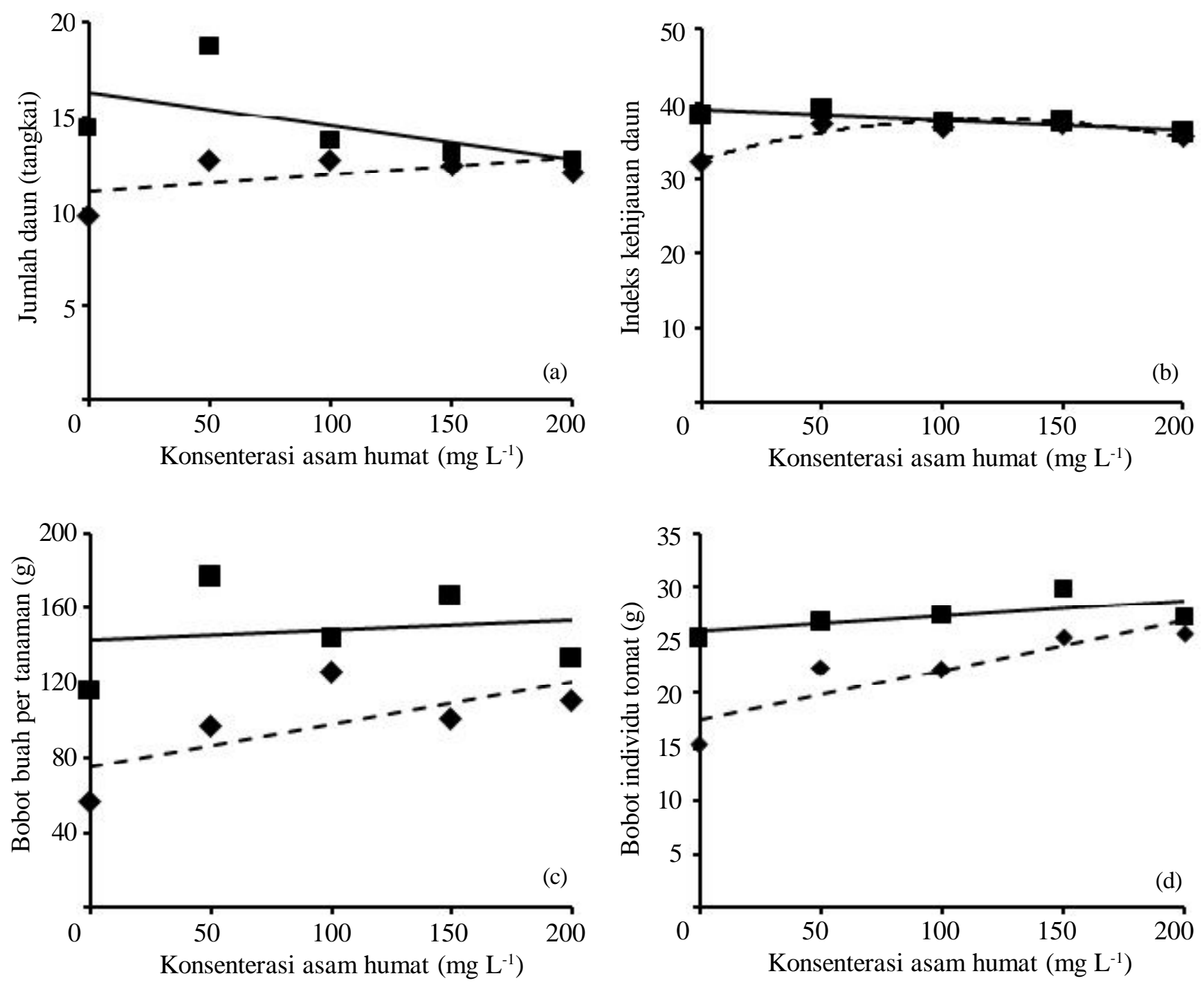

Gambar 1. Hubungan interaksi antara asam humat dengan pupuk $\mathrm{K}$ terhadap (a) jumlah daun : $\mathrm{Y}_{\mathrm{k} 1}=-0,018 \mathrm{x}+$ 16,267 dan $R^{2}=0,342 * \& Y_{k 0}=0,009 x+11$ dan $R^{2}=0,295^{* *}(b)$ indeks kehijauan daun: $Y_{k 1}=-0,014 x$ $+39,127$ dan $R^{2}=0,80714 * * \& Y_{k 0}=-0,00036 x^{2}+0,08598 x+32,69714$ dan $R^{2}=0,88875^{* *}$, (c) bobot tomat per butir: $\mathrm{Y}_{\mathrm{k} 1}=0,0515 \mathrm{x}+143,333$ dan $\mathrm{R}^{2}=0,0275$ tn $\& \mathrm{Y}_{\mathrm{k} 0}=0,225 \mathrm{x}+76,00$ dan $\mathrm{R}^{2}=0,466^{* *}$, (d) bobot buah per tanaman: $\mathrm{Y}_{\mathrm{k} 1}=0,0139 \mathrm{x}+25,831$ dan $\mathrm{R}^{2}=0,435^{* *} \& \mathrm{YK} 0=0,0465 \mathrm{x}+17,553$ dan $\mathrm{R}^{2}=0,79973^{* *}$. $=\mathrm{k} 0($ Tanpa $\mathrm{KCl}), \boldsymbol{\square}=\mathrm{k} 1$ (dengan pupuk KCl $\left.6 \mathrm{~g} \mathrm{polybag}^{-1}\right)$.

linier. Hal tersebutmenunjukkan bahwa pemberian asam humat pada tanaman akan efektif bila kadar $\mathrm{K}$ di dalamtanah rendah, namun bila kadar $\mathrm{K}$ telah cukup optimal maka pengaruh nya menjadi tidak nyata. Oleh karena itu, pemberian asam humat melalui daun dapat mengurangi pupuk kimia.Hal ini sejalan dengan Shaabandkk.(2010) yang mendapatkan bahwa pemberian asam humat melalui daun dapat mengurangi penggunaan pupuk NPK. Dia menjelaskan bahwa dengan mengurangi penggunaan pupuk NPK melalui tanah sebesar $25 \%$ yang diikuti dengan penyemprotan asam humat $7,5 \mathrm{~cm} \mathrm{ml}^{-1}$, dapat meningkatkan panjang tangkai, berat tangkai, dan biji. Hasil jerami tertinggi diperoleh pada pengurangan pupuk NPK sebesar 50\% dengan diikuti penyemprotan asam humat dengan dosis $5 \mathrm{~cm} \mathrm{ml}^{-1}$.

\section{KESIMPULAN}

Dari hasil penelitian dapat disimpulkan bahwa pertumbuhan dan produksi tanamn tomat dipe-ngaruhi oleh interaksi asam humat dan K. Pada tanpa K, pemberian asam humat meningkatkan jumlah daun, bobot buah per tanaman, bobot individu tomat meningkat secara 
linier dan indeks kehijauan daun meningkat secara kuadratik, tetapi bila dipupuk K hubungannya tidak nyata terhadap bobot buah per tanaman, kecuali untuk junlah daun dan indeks kehijauan daun menurun secara linier. Oleh karena itu disarankan untuk melakukan penelitian lebih lanjut tentang pengaplikasian asam humat terhadap pertumbuhan dan produksi tanaman tomat dengan konsentrasi yang ditingkatkan.

\section{DAFTAR PUSTAKA}

El- Ghamry, A.M. K.A. El-Hai and K.M. Ghoneem. 2009. Amino and humic acids promote growth, yield and disease resistance of faba bean cultivated in clayey soil. Aust. J. Basic Appl. Sci., 3(2): 731-739.

Ferrara. G and G. Brunetti. 2010. Effect of the times of aplication of a soil humic acid on berry quality of table grape (Vitis vinifera L.) cv Italia. Spanish J. Agric. Res. 8 (3) : 817-822.

Hanafiah, K.A. 2005. Dasar-Dasar Ilmu Tanah. PT Raja Grafindo Persada. Jakarta. 295 hal.

Heil, C.A.2005. Influence of humic, fulvic and hydrophilic acids on the growth, photosynthesis and respiration of the dinoflagelatte Prorocentrum minimum (Pavillard) Schiller. Harmful Algae 4: 603-618.

Mulyati, R.S. Tejowulan, V.A. Oktarina. 2007. Respon tanaman tomat terhadap pemberian pupuk kandang ayam dan urea terhadap pertumbuhan dan serapan N. J. Agroteksos. 17 (1) : 51-56.
Mylonas, V.A. and C.B. McCants. 1980. Effects of humic and fulvic acids on growth of tobacco. 2 . tobacco growth and ion uptake. J. Plant Nutr. 2 (3) : 377-393.

Nugroho, 2011. Peran konsentrasi pupuk daun dan dosis pupuk kalium terhadap hasil tanaman tomat (Lycopersicum esculentum Mill). J. Politeknosains Edisi Khusus Dies Natalis. :3543

Pitojo, S. 2005. Benih Tomat. Kanisius, Yogyakarta. 91 hal.

Sarno dan Eliza, F. 2011. Pengaruh pemberian asam humat dan pupuk $\mathrm{N}$ terhadap pertumbuhan dan serapan N pada tanaman bayam. Prosiding SNSMAIP III: 289-293.

Shaaban, S.H.A. F.M. Manal, and M.H.M. Afifi. 2009. Humic acid foliar application to minimaize soil applied fertilization on surface-irigated wheat. World J. Agric. Sci. 5 (2) : 207-2010.

Syakir, M. dan Gusmaini. 2012. Pengaruh penggunaan sumber pupuk kalium terhadap produksi dan mutu minyak tanaman nilam. J. Littri. 18 (2) : 60-65.

Tan, K. H. 1993. Dasar-dasar Kimia Tanah. Diterjemahkan oleh Didiek Hajdar Goenadi. Marcel Gajah Mada University Press. 295 hal. 